\title{
Analisis Hubungan Penganggaran Partisipatif dan Kinerja: Pengujian Efek Mediasi Keadilan Persepsian dan Komitmen pada Lembaga Hukum Sektor Publik di Indonesia
}

\author{
Rahmia Hasniasari ${ }^{1}$; Mahfud Sholihin ${ }^{2 *}$ \\ ${ }^{1}$ Badan Supervisi Bank Indonesia (Supervisory Board of Bank Indonesia) \\ ${ }^{2}$ Jurusan Akuntansi, Fakultas Ekonomi, Universitas Gadjah Mada, Bulaksumur, Yogyakarta \\ Daerah Istimewa Yogyakarta 55281 \\ * Korespondensi penulis, email: mahfud@ugm.ac.id
}

\begin{abstract}
ABSTRAK
Penelitian ini membahas apakah penganggaran partisipatif mempengaruhi kinerja, dan jika demikian, apakah pengaruh tersebut dimediasi oleh keadilan persepsian dan komitmen terhadap tujuan. Penelitian ini dilakukan pada organisasi publik, yaitu lembaga hukum, di Indonesia. Penelitian sebelumnya (Wentzel 2002) telah menguji model ini di sebuah rumah sakit di Amerika Serikat. Studi ini menemukan bahwa: (1) penganggaran partisipatif positif mempengaruhi kinerja manajerial; (2) pengaruh tersebut dimediasi sebagian oleh keadilan prosedural dan komitmen terhadap tujuan.
\end{abstract}

Kata kunci: akuntansi keperilakuan, anggaran partisipatif, keadilan persepsian, komitmen, kinerja.

\begin{abstract}
This paper examines whether participative budgeting influences performance, and if so, whether the effect is mediated by perceived justice and goal commitment. The research setting of this study is a public organization, i.e. law institution, in Indonesia. Prior study (Wentzel 2002) had examined this model in a hospital in the United States. Our study finds that: (1) participative budgeting positively influences managerial performance; (2) the influence is partially mediated by procedural justice and goal commitment.
\end{abstract}

Keywords: behavioral accounting, participative budgeting, perceived justice, commitment, performance.

\section{PENDAHULUAN}

Berbagai studi di bidang akuntansi keperilakuan menyatakan bahwa hubungan antara partisipasi pada proses penganggaran (participative budgeting) dan kinerja (performance) cukup kompleks dan tidak selalu konsisten (Lau dan Tan 2006 dalam Lau dan Moser 2008; Nouri dan Parker 1998). Beberapa peneliti menemukan hubungan antara partisipasi pada penganggaran dan kinerja adalah negatif (Stedry 1960; Bryan dan Locke 1967 dalam Nouri dan Parker 1998), namun ada pula yang menemukan hubungan positif antara kedua variabel tersebut (Argyris 1952 dalam Nouri dan Parker 1998; Becker dan Green 1962). Beberapa peneliti menemukan bahwa pengaruh partisipasi pada penganggaran terhadap kinerja tidak signifikan (Merchant 1981 dalam Nouri dan Parker 1998; Brownell 1982).

Magner dan Welker (1994) serta Magner dan Johnson (1995) dalam Linquist (1995) mengemukakan bahwa keadilan persepsian (perceived fairness) adalah salah satu variabel penting yang dapat memediasi hubungan partisipasi pada penganggaran terhadap kinerja. Beberapa peneliti lain mendukung temuan tersebut (Linquist 1995; Libby 1999). Partisipasi dalam organisasi dianggap memungkinkan adanya rasa diperlakukan secara adil sehingga dapat mendorong individu untuk meningkatkan kinerja.

Lau dan Moser (2008) menemukan bahwa hubungan antara keadilan persepsian dan kinerja dimediasi oleh komitmen terhadap tujuan (goal commitment). Prosedur yang dilaksanakan dengan 
adil secara positif berpengaruh terhadap kinerja karena persepsi diperlakukan secara adil dapat memotivasi individu untuk meningkatkan komitmen terhadap tujuan yang ditetapkan oleh organisasi (Lind et al. 1990 dalam Lau dan Moser 2008).

Penelitian-penelitian terdahulu mengindikasikan bahwa keadilan persepsian dan komitmen terhadap tujuan merupakan dua variabel penting yang dapat menghubungkan partisipasi pada penganggaran dan kinerja. Wentzel (2002) melakukan penelitian hubungan antara partisipasi penganggaran dan kinerja dengan variabel pemediasi keadilan persepsian dan komitmen terhadap tujuan di sebuah rumah sakit perkotaan di Amerika Serikat yang sedang mengalami pemotongan anggaran. Penelitian Wentzel (2002) membuktikan bahwa keadilan persepsian memediasi hubungan antara partisipasi pada penganggaran dan komitmen terhadap tujuan, sedangkan komitmen terhadap tujuan memediasi hubungan antara keadilan persepsian dan kinerja. Hanya saja, tidak ada kejelasan apakah temuan Wentzel (2002) dapat digeneralisasi pada sektor dan/atau di negara lain. Penelitian ini dilakukan untuk mereplikasi dan memperluas temuan Wentzel (2002) dengan melakukan penelitian pada lembaga hukum pada sekotor publik di Indonesia.

Secara spesifik penelitian ini akan menguji apakah partisipasi pada penganggaran mempengaruhi kinerja, dan apakah keadilan persepsian dan komitmen terhadap tujuan anggaran memediasi hubungan antara partisipasi pada penganggaran dan kinerja di lembaga hukum pada sektor publik di Indonesia. Model penelitian disajikan dalam Gambar 1.

Alasan pertama mengapa penelitian ini penting adalah untuk menganalisis apakah kesimpulan Wentzel (2002) juga berlaku pada organisasi yang tidak sedang dalam pemotongan anggaran. Kedua, peneliti ingin mengetahui apakah generalisasi Wentzel (2002) berlaku pada sektor publik di Indonesia karena menurut Jermias dan Setiawan (2007) organisasi sektor publik di Indonesia memiliki karakter khusus dan penting untuk dipelajari. Ketiga, peneliti akan menganalisis pengaruh partisipasi penganggaran terhadap kinerja di institusi nonkeuangan, setelah Jermias dan Setiawan (2007) melakukan penelitian mengenai penganggaran di organisasi sektor publik di Indonesia di bidang keuangan.

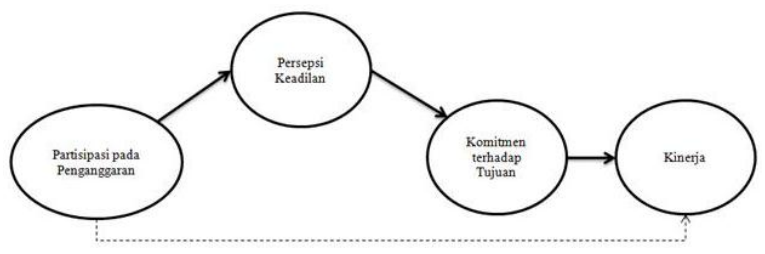

Gambar 1. Model Penelitian
Dengan menggunakan sampel 52 anggota sebuah lembaga hukum sektor publik di Indonesia yang ikut serta dalam proses penganggaran, penelitian ini menemukan kesimpulan bahwa partisipasi pada penganggaran berhubungan dengan kinerja. Penelitian ini juga menemukan bahwa keadilan prosedural dan komitmen terhadap tujuan memediasi hubungan antar partisipasi pada penganggaran dan kinerja.

Setelah pendahuluan, artikel ini akan menyajikan kerangka teori dan pengembangan hipotesis. Setelah itu akan disajikan metodologi penelitian yang diikutihasil penelitian dan analisis. Artikel ini akan ditutup dengan kesimpulan, implikasi dan keterbatasan penelitian.

\section{Partisipasi pada Penganggaran dan Kinerja}

Partisipasi pada penganggaran merupakan kegiatan penyusunan anggaran dengan melibatkan pihak-pihak terkait dalam organisasi, agar hasil dari pengambilan keputusan tersebut dapat sesuai dengan kebutuhan organisasi. Partisipasi karyawan dalam proses menentukan anggaran memberikan kesempatan pada atasan untuk meningkatkan akses pada informasi lokal (local information) (Baiman 1982; Baiman dan Evans 1983; Magee 1980) yang terjadi pada setiap bagian di dalam organisasi, sehingga dapat mereduksi informasi yang asimetris. Informasi lokal yang tidak dimiliki oleh atasan akan mempengaruhi proses pembuatan keputusan mengenai penganggaran (Evan 1983; Coughlan dan Schmidt 1985; dan Penno 1984).

Kinerja pada konteks manajemen mencakup perencanaan dan prosedur yang terintegrasi dan diturunkan melalui organisasi untuk memberikan ikatan antara masing-masing individu dan strategi organisasi secara keseluruhan (Roger 1990). Pollitt (1999) dalam Smith dan Goddard (2002) menggambarkan kinerja manajerial sebagai aturan dari lima proses yang ada pada organisasi, yaitu: (1) penentuan tujuan, (2) penugasan kewajiban, (3) pengukuran kinerja, (4) umpan balik informasi untuk pengambilan keputusan, dan (5) akuntabilitas. Argyris (1952) berargumen bahwa peningkatan kinerja karyawan bisa terjadi jika karyawan diikutsertakan dalam proses penganggaran. Partisipasi dalam penganggaran dapat meningkatkan motivasi sehingga meningkatkan kinerja seseorang (Nouri dan Parker 1998). Berdasar pada berbagai penjelasan di atas, peneliti berkeyakinan untuk membangun hipotesis sebagai berikut:

H1a: Partisipasi pada penganggaran berhubungan secara positif terhadap kinerja manajerial.

H1b: Partisipasi pada penganggaran berhubungan secara positif terhadap kinerja anggaran. 
Partisipasi pada Penganggaran dan Keadilan Persepsian (Perceived Fairness)

Thibaut dan Walker (1975) dalam Wentzel (2002) mengatakan keadilan persepsian ditentukan oleh proses kontrol (partisipasi) yang dipengaruhi berbagai keputusan dan konsekuensi dari adanya hasil yang merata. Pengertian lebih lanjut mengatakan bahwa keadilan persepsian adalah penilaian terhadap bagaimana norma sosial berhubungan dengan proses pembuatan keputusan dan bagaimana seseorang diperlakukan oleh atasan dan pihak lainnya (Lind dan Tyler 1988). Teori self-interest menghubungkan partisipasi pada penganggaran dan keadilan pesepsian (Lind dan Tyler 1988; Tyler 1989 dalam Wentzel 2002). Konsep tersebut meliputi konsep efek yang berdasarkan hasil (outcome-based) (Lau et al. 2008) yang menerangkan bahwa seseorang memperhatikan keikutsertaan dalam proses organisasi karena mereka melihat pada hasil yang akan didapatkan dari kegiatan tersebut. Persepsi individu terhadap keadilan akan meningkat saat seseorang diberikan kesempatan untuk berpartisipasi karena meyakini bahwa keikutsertaan tersebut penting untuk mencapai tujuan yang diharapkan.

Keadilan persepsian dapat dijelaskan melalui dua bentuk, yaitu keadilan prosedural (procedural justice) yang dirasakan dalam kebijakan atau prosedur, digunakan dalam membuat keputusan (Folger dan Greenberg 1983); dan keadilan distributif (distributive justice) yang menilai keadilan akan hasil sesungguhnya yang didapatkan oleh individu dalam organisasi (Greenberg 1987).

Leventhal (1976) mendefinisikan keadilan distributif sebagai kepercayaan pada individu bahwa suatu hal telah adil saat upah, hukuman, atau sumber daya yang didistribusikan telah sesuai dengan kriteria tertentu. Aturan prosedural (keadilan prosedural) oleh Leventhal (1980) dalam Sholihin et al. (2011) didefinisikan sebagai kepercayaan individu bahwa prosedur yang dialokasikan secara tepat yang memenuhi kriteria tertentu adalah adil dan tepat. Sholihin et al. (2011) mengintepretasikan empat dari enam karakter keadilan yang dijabarkan oleh Leventhal (1980) dapat didorong oleh partisipasi pada penentuan tujuan, salah satunya dalam proses partisipasi anggaran yang merupakan aturan tentang keterwakilan (representative rule). Menurut Sholihin et al. (2011) membiarkan karyawan untuk merefleksikan kepedulian, nilai, dan memberikan kesempatan untuk memodifikasi keputusan sehingga dapat dijadikan alat untuk berbagi informasi. Wentzel (2002) membuktikan bahwa partisipasi pada penganggaran berpengaruh pada keadilan distributif dan keadilan prosedural. Berdasarkan berbagai pembahasan di atas, maka peneliti membangun hipotesis sebagai berikut:

H2a: Partisipasi pada penganggaran berhubungan secara positif terhadap keadilan persepsian distributif.

H2b: Partisipasi pada penganggaran berhubungan secara positif terhadap keadilan persepsian prosedural.

\section{Partisipasi pada Penganggaran dan Komit- men terhadap Tujuan (Goal Commitment)}

Semakin banyak partisipasi dalam pembuatan keputusan, semakin kuat tendensi karyawan untuk mengenali organisasinya (March dan Simon 1958 dalam Nouri dan Parker 1998). Partisipasi mengintegrasikan pekerja dalam berkomitmen pada keputusan organisasi (Lincoln dan Kalleberg 1985 dalam Nouri dan Parker 1998). Komitmen untuk mencapai tujuan dapat ditimbulkan dari partisipasi anggota dalam menentukan tujuan organisasi (Locke 1968).

Locke et al. (1988) mengemukakan bahwa komitmen terhadap tujuan merupakan derajat komitmen individu untuk mencapai tujuan tertentu dan merupakan aspek kunci dari teori penetapan tujuan (goal-setting theory). Teori penetapan tujuan (goal setting theory) adalah teori yang berfokus pada pada identifikasi jenis tujuan yang paling efektif untuk menghasilkan motivasi dan kinerja pada tingkatan yang tinggi, dan menjelaskan mengapa tujuan tersebut memiliki dampak (George dan Jones 2006).

Terdapat beberapa temuan penting yang berhubungan dengan goal commitment, yaitu kinerja tugas (task performance) (Donovan dan Radosevich 1998 dalam Li dan Butler 2004), dan akuisisi keterampilan (Seijts dan Latham 2001 dalam Li dan Butler 2004). Komitmen terhadap tujuan ditandai dengan tekad untuk memperkuat usaha searah dengan tujuan dari waktu ke waktu (Hollenbeck dan Klein 1987 dalam Li dan Butler 2004).

Chong dan Chong (2002) mengemukakan bahwa saat seseorang memiliki kesempatan untuk terlibat dalam pembuatan keputusan, maka ia akan meningkatkan komitmennya pada tercapainya tujuan organisasi. Nouri dan Parker (1998) menemukan adanya hubungan positif antara partisipasi pada penganggaran dan komitmen terhadap anggaran dari hasil survey yang ia lakukan pada pada manajer di berbagai perusahaan besar di Amerika Serikat. Berdasarkan berbagai penjelasan tersebut peneliti membangun hipotesis sebagai berikut:

H3: Partisipasi pada penganggaran berhubungan secara positif terhadap komitmen terhadap tujuan. 


\section{Keadilan Persepsian dan Komitmen terhadap Tujuan}

Beberapa peneliti menemukan bahwa terdapat hubungan yang positif antara keadilan persepsian dan komitmen (Earley dan Lind 1987 dalam Wentzel 2002; dan Lind et al. 1990 dalam Wentzel 2002; dan Korsgaard et al. 1995). Alasan yang dikemukakan Wentzel (2002) dalam hubungan tersebut adalah saat karyawan memiliki persepsi bahwa saat suatu keputusan dibuat dengan proses yang adil, maka komitmennya pada tujuan organisasi akan meningkat; disebabkan hasil keputusan yang ada diharapkan sesuai dengan kepentingan mereka.

Teori instrumental (instrumental theory) yang dibangun oleh Thibaut dan Walker (1975) dalam Lau dan Moser (2008) menyatakan bahwa seseorang lebih banyak memperhatikan pada penerimaan hasil sesuai yang diharapkan, mereka menyukai prosedur yang adil karena akan membuahkan hasil yang adil (Lau dan Moser 2008). Adanya perasaan diperlakukan adil dapat memberikan beberapa dampak positif, di antaranya berupa loyalitas, komitmen, dan kinerja yang bagus dari karyawan (Lau dan Moser 2008). Keadilan sistem evaluasi menjadi penentu perilaku karyawan yang diharapkan dapat meningkatkan komitmen dan kinerja (Lind dan Tyler 1988; Lau dan Lim 2002 dalam Lau et al. 2008).

Lau et al. (2008) telah membuktikan bahwa terdapat hubungan positif antara keadilan persepsian terhadap komitmen untuk mencapai tujuan pada organisasi yang bergerak di bidang kesehatan di Australia. Peneliti berkeyakinan bahwa keadilan persepsian turut berperan dalam meningkatkan komitmen individu di dalam organisasi, berdasarkan berbagai pembahasan di atas, maka peneliti membangun hipotesis sebagai berikut:

H4a: Keadilan distributif berhubungan secara positif terhadap komitmen terhadap tujuan.

H4b: Keadilan prosedural berhubungan secara positif terhadap komitmen terhadap tujuan.

\section{Komitmen terhadap Tujuan dan Kinerja}

Tercapainya tujuan merupakan salah satu indikator bahwa organisasi memiliki kinerja yang baik. Tujuan yang telah ditentukan tidak akan tercapai saat tidak terdapat komitmen terhadap tujuan tersebut (Locke et al. 1988). Affective goal commitment merupakan kemauan seseorang untuk melakukan usaha yang besar untuk kepentingan organisasi, hal tersebut merupakan alasan mengapa komitmen terhadap tujuan berpengaruh positif terhadap kinerja (Lau dan Moser 2008).
Bennis dan Nanus (1985) dalam Locke et al. (1988) mengemukakan bahwa komitmen pada tujuan akan meningkatkan efektivitas manajemen. Peningkatan efektivitas manajemen merupakan salah satu faktor penting dalam peningkatan kinerja di dalam organisasi. Lau dan Moser (2008) membuktikan bahwa terdapat hubungan yang positif antara komitmen terhadap tujuan dan kinerja melalui survey yang ia lakukan di beberapa organisasi manufaktur di Inggris. Berdasarkan berbagai penjelasan di atas, peneliti berkeyakinan bahwa, dan membangun hipotesis sebagai berikut:

H5a: Komitmen terhadap tujuan berhubungan secara positif terhadap kinerja manajerial.

H5b: Komitmen terhadap tujuan berhubungan secara positif terhadap kinerja anggaran.

\section{METODE PENELITIAN}

\section{Objek Penelitian dan Sampel}

Penelitian ini dilakukan pada sebuah institusi hukum tingkat nasional di Indonesia yang bertugas untuk memilih hakim agung dan mengawasi kerja hakim di berbagai tingkatan. Organisasi ini memiliki populasi yang cukup kecil, yaitu sebanyak 165 orang yang terdiri dari tujuh komisioner, seorang sekjen, lima kepala biro, 12 kepala bagian, dan staf. Sampel yang diambil sebagai data adalah anggota institusi yang pernah ikut dalam proses penyusunan anggaran, sehingga mereka memahami pertanyaan yang diajukan.

Penganggaran pada institusi tersebut dilakukan oleh perwakilan setiap biro yang mengetahui secara spesifik program yang mereka lakukan. Selain anggota institusi, proses penganggaran juga dilakukan oleh Direktorat Jenderal Anggaran Kementerian Keuangan (DJA Kemenkeu) dan Badan Perencanaan Pembangunan Nasional (Bappenas) dengan membuat pagu indikatif yang harus ditaati. Dengan adanya pagu indikatif, sebuah lembaga tidak dapat menyusun penganggaran yang jauh berbeda dari pagu tersebut.

Sebelum menyusun kuesioner peneliti melakukan observasi pada objek penelitian untuk mengetahui karakter dari organisasi ini. Pemahaman tersebut dianggap penting oleh peneliti demi mengetahui relevansi dan kesesuaian objek penelitian dengan tujuannya. Kuesioner diberikan pada 60 nama yang telah ditentukan oleh peneliti berdasarkan keikutsertaan dan pemahamannya dalam hal penganggaran.

\section{Instrumen Pengukuran}

Penelitian ini merupakan replikasi dari studi terdahulu yang telah dilakukan oleh Wentzel (2002), sehingga pengukuran pada variabelnya 
menggunakan instrumen yang telah dipakai oleh penelitian tersebut. Pendekatan ini memungkinkan untuk membandingkan hasil ini dengan penelitian Wentel (2002). Instrumen yang digunakan oleh Wentzel (2002) menggunakan tujuh poin skala Likert yang merupakan skala yang didesain untuk menentukan seberapa kuat subjek menyetujui atau tidak menyetujui suatu pernyataan yang ada di dalam kuesioner. Detil penjelasan kuesioner yang dipakai adalah sebagai berikut.

\section{Partisipasi pada Penganggaran}

Variabel ini diukur dengan menggunakan butir pengukur yang dibuat oleh Milani (1975) dalam Wentzel (2002). Responden ditanya tentang tingkat keikutsertaan mereka pada proses penganggaran. Instrumen ini cukup populer dan kredibel dalam penelitian mengenai partisipasi penganggaran terbukti dengan telah digunakannya skala Milani (1975) pada studi yang dilakukan oleh Linquist (1995), Nouri dan Parker (1998), dan Sholihin et al. (2011). Wentzel (2002) memperhatikan pengaruh pada restrukturasi yang terjadi pada objek penelitiannya sehingga memasukkan pengukuran tentang partisipasi pada penganggaran di dalam level organisasi dengan menanyakan keikutsertaan mereka dalam tim yang dirombak. Melihat tidak ada restrkturisasi dalam organisasi pada objek penelitian ini, maka butir tersebut tidak digunakan.

\section{Keadilan Persepsian}

Dua bentuk keadilan persepsian diukur pada penelitian ini, yaitu keadilan prosedural dan keadilan distributif. Keadilan prosedural diukur dengan menggunakan empat butir instrumen yang dibuat Magner dan Johnson (1995) dalam Wentzel (2002) yang mengacu pada lima aturan keadilan yang dijabarkan oleh Leventhal (1980); mencakup konsistensi antar perseorangan dan waktu, akurasi, etika, dan pengurangan bias. Keadilan distributif diukur menggunakan lima butir yang dikembangkan Magner dan Johnson (1995). Skala ini dibuat untuk digunakan dalam pengukuran beberapa dasar komparatif pada lingkungan penganggaran, yaitu kebutuhan, ekspektasi, dan kepantasan (Magner dan Johnson 1995). Seperti halnya yang telah dilakukan Wentzel (2002), satu butir pengukuran tambahan terhadap keadilan distributif dimasukan ke dalam penelitian ini, yaitu aspek keadilan distributif yang dibuat oleh Greenberg (1993).

\section{Komitmen terhadap Tujuan Anggaran}

Tiga butir pengukuran yang dikembangkan oleh Latham dan Steele (1983) digunakan untuk mengukur variabel ini. Instrumen ini mengukur bagaimana individu berkomitmen pada tujuan tertentu dan perjuangan mereka untuk mencapainya (Wentzel 2002). Pemilihan instrumen Latham dan Steele (1983) dilatarbelakangi oleh konteks kegiatan partisipasi pada penganggaran yang menjadi variabel independen pada model dalam penelitian ini. Aplikasi pengukuran ini juga telah digunakan oleh Wentzel (2002) dalam penelitian sejenis.

\section{Kinerja}

Pada penelitian ini dilakukan pengukuran dua tipe kinerja, yaitu kinerja manajerial dan kinerja penganggaran sebagaimana yang telah dilakukan oleh Wentzel (2002). Kinerja manajerial diukur menggunakan instrumen Mahoney et al. (1963) yang menanyakan responden tentang kinerja mereka dalam delapan dimensi, yaitu: perencanaan, investigasi, koordinasi, evaluasi, supervisi, staffing, negosiasi, dan mewakili. Kinerja penganggaran diukur dengan meminta responden untuk memberikan penilaian pada kinerja penganggaran di organisasi yang diteliti sebagaimana yang telah dilakukan Wentzel (2002). Kedua pengukur ini cukup handal dan pernah digunakan oleh beberapa peneliti lainnya, salah satunya Linquist (1995).

Statistik deskriptif dari variabel yang diteliti, mencakup nilain mean, minimum, maksimum, dan standar deviasi dapat dilihat di Tabel 1. Dari tabel tersebut dapat dikatakan bahwa rata-rata nilai respon adalah tinggi, yaitu partisipasi pada anggaran $(4,69)$, rata-rata sampel berpersepsi bahwa keadilan prosedural pada organisasinya lebih tinggi $(4,79)$ daripada keadilan distributif $(4,41)$. Respon pada variabel komitmen terhadap tujuan adalah yang paling tinggi $(5,56)$, menunjukkan bahwa sampel cenderung memiliki komitmen untuk bekerja sesuai dengan tujuan organisasi. Kinerja anggaran pada organisasi tersebut dinilai lebih tinggi $(4,88)$ dibandingkan kinerja managerial $(4,52)$.

\section{Tabel 1. Statistik Deskriptif}

\begin{tabular}{lccccccc}
\hline & \multicolumn{3}{c}{$\begin{array}{c}\text { Theoritical } \\
\text { Score }\end{array}$} & \multicolumn{2}{c}{$\begin{array}{c}\text { Actual } \\
\text { Score }\end{array}$} & Mean & SD \\
\cline { 2 - 6 } & Min & Max & Min & Max & & \\
\hline Partisipasi pada & 1 & 7 & 1 & 7 & 4,693 & 1,416 \\
$\begin{array}{l}\text { Penganggaran } \\
\text { Keadilan Prosedural }\end{array}$ & 1 & 7 & 7 & 1 & 4,790 & 1,425 \\
Keadilan Distributif & 1 & 7 & 7 & 1 & 4,409 & 1,539 \\
Komitmen terhadap & 1 & 7 & 7 & 1 & 5,565 & 1,359 \\
Tujuan & & & & & & \\
Kinerja Managerial & 1 & 7 & 7 & 1 & 4,523 & 1,662 \\
Kinerja Anggaran & 1 & 7 & 7 & 1 & 4,878 & 1,114 \\
\hline
\end{tabular}




\section{Metode Analisis}

Alat analisis yang digunakan dalam penelitian ini adalah partial least square (PLS) yang merupakan teknik statistika multivariat yang melakukan perbandingan antara variabel dependen berganda dan variabel independen berganda. Hal yang menjadi alasan pemilihan metoda tersebut dalam penelitian ini adalah: (1) penggunaan OLS (ordinary least square) tidak tepat untuk menganalisis model dengan lebih dari satu variabel dependen dikarenakan alasan multikolineritas; (2) PLS merupakan SEM berbasis varian yang dapat memprediksi model untuk mengembangkan teori, (3) hasil yang akan didapatkan dari olah data menggunakan PLS tetap kokoh meskipun terdapat data yang tidak normal atau hilang, (4) dapat digunakan pada sampel kecil, (5) dapat digunakan pada data dengan berbagai tipe skala (Hartono dan Abdillah 2009).

\section{Model Pengukuran}

Model pengukuran atau outer model dievaluasi dengan memeriksa validitas dan reliabilitas pada konstruk. Validitas dievaluasi dengan memeriksa validitas konvergen dan diskriminan dari masing-masing indikator.

Validitas konvergen diukur dengan melihat outer loadings dan average variance extracted (AVE). Jika nilai outer loadings kurang dari 0,7 , indikator ini dapat dihapus dari konstruknya karena indikator ini tidak termuat (load) ke konstruk yang mewakilinya. Indikator juga bisa dikatakan valid jika memiliki nilai AVE lebih dari 0,5 yang artinya probabilitas indikator tersebut konvergen dan masuk pada konstruk yang dimaksud lebih besar, yaitu 0,5 (Chin 1995 dalam Hartono dan Abdillah 2009). Uji validitas diskriminan dapat dilakukan dengan melihat nilai cross loading. Validitas diskriminan yang baik dapat dilihat dari nilai cross loading pada indikator pada variabel laten di dalam model, perbedaan yang signifikan antar indikator pada variabel latennya dibanding variabel lain dalam konstruk akan menguatkan asumsi validitas diskriminan. Reliabilitas model akan diukur dengan melihat Cronbachs Alpha dan composite reliability.

\section{Model Struktural}

Evaluasi model struktural dilakukan untuk memprediksi hubungan kausal antarvariabel atau pengujian hipotesis (Hartono dan Abdillah 2009). Model struktural atau inner model dengan PLS dievaluasi dengan memeriksa persentase varian yang dijelaskan dengan nilai $R$-square dari variabel independen laten. Stabilitas pada estimasi dapat akan dievaluasi dengan menggunakan t-test melalui proses bootstrapping.

Analisis model struktural dilakukan untuk melihat korelasi antara hipotesis. Sebelum melakukan analisis model struktural tersebut, peneliti melakukan pengujian bivariate correlation dan multivariate correlation di dalam model.

\section{HASIL ANALISIS DAN PEMBAHASAN}

\section{Analisis Mode Pengukuran}

Hampir seluruh indikator memiliki validitas konvergen yang baik karena nilai dari outer loadings yang dimiliki lebih dari 0,7 (lihat Tabel 2). Uji validitas diskriminan menunjukkan perbedaan yang signifikan pada value of loading pada indikator terhadap variabel latennya dibandingkan variabel lain. Dengan kata lain, semua indikator telah memenuhi syarat validitas diskriminannya. Selain itu, nilai Cronbachs Alpha dan composite reliability pada variabel-variabel dalam model ini rata-rata memiliki nilai lebih dari 0,8. Dengan terpenuhinya ketentuan tersebut, instrumen pada penelitian ini dapat dikatakan reliable, dan dapat mengindikasikan adanya akurasi, konsistensi, dan presisi yang signifikan pada instrumen dalam mengukur variabel.

Dari pengujian korelasi bivariat yang dilakukan pada penelitian ini, ditemukan bahwa kebanyakan variabel memiliki hubungan yang sangat signifikan satu sama lain (lihat Tabel 3). Dua hubungan variabel yang tidak signifikan karena memiliki $t$-statistics di bawah $t$-table adalah hubungan antara keadilan distributif dan kinerja anggaran, serta hubungan antara keadilan prosedural dengan kinerja anggaran.

Tabel 3 mmnunjukkan bahwa partisipasi pada penganggaran berhubungan dengan kinerja manajerial $(\mathrm{r}=0,628 ; \mathrm{p}<0,01)$ dan kinerja anggaran $(r=0.368 ; p<0,01)$. Selain itu partisipasi pada penganggaran berkorelasi dengan komitmen terhadap tujuan $(\mathrm{r}=0.619 ; \mathrm{p}<0,01)$. Partisipasi pada penganggaran mempengaruhi persepsi dua jenis keadilan persepsian, yaitu pada keadilan distributif $(\mathrm{r}=0.451 ; \mathrm{p}<0,01)$ dan keadilan prosedural $(\mathrm{r}=0.346$; $\mathrm{p}<0,01)$. Selain itu, dua jenis keadilan persepsian berpengaruh pada komitmen terhadap tujuan, yaitu keadilan distributif $(r=0.444 ; p<0.01)$, dan keadilan prosedural $(\mathrm{r}=0.476 ; \mathrm{p}<0,01)$. Komitmen terhadap tujuan anggaran juga berhubungan dengan kinerja manajerial $(\mathrm{r}=0.563 ; \mathrm{p}<0,01)$ dan kinerja anggaran $(r=-0.424 ; \mathrm{p}<0,01)$. 
Tabel 2. Validitas dan Reliabilitas

\begin{tabular}{|c|c|c|c|}
\hline Variabel Laten & Mean & $\mathrm{SD}$ & Loading \\
\hline \multicolumn{4}{|c|}{$\begin{array}{l}\text { Partisipasi pada Penganggaran (PP), Con } \\
0,879 ; \text { AVE }=0,548 \text {; Cronbachs Alfa }=0,834\end{array}$} \\
\hline PP1 & 5.096 & 1,241 & 0,699 \\
\hline PP2 & 4.442 & 1,487 & 0,708 \\
\hline PP3 & 4.327 & 1,478 & 0,779 \\
\hline PP4 & 4.569 & 1,432 & 0,803 \\
\hline PP5 & 5.462 & 1,275 & 0,698 \\
\hline PP6 & 4.635 & 1,314 & 0,749 \\
\hline \multicolumn{4}{|c|}{$\begin{array}{l}\text { Keadilan Prosedural (KP); Composite reliability }=0,865 ; \text { AVE }= \\
0,565 ; \text { Cronbachs Alfa }=0,817\end{array}$} \\
\hline $\mathrm{KP} 1$ & 5.288 & 1.593 & 0.622 \\
\hline KP2 & 5.192 & 1.362 & 0.776 \\
\hline KP3 & 5.442 & 1.456 & 0.830 \\
\hline KP4 & 4.615 & 1.349 & 0.651 \\
\hline KP5 & 4.731 & 1.316 & 0.829 \\
\hline KP6 & 4.558 & 1.510 & 0.599 \\
\hline KP7 & 4.538 & 1.335 & 0.826 \\
\hline KP8 & 4.769 & 1.527 & 0.778 \\
\hline \multicolumn{4}{|c|}{$\begin{array}{l}\text { Keadilan Distributif }(\mathrm{KD}) ; \text { Composite reliability }=0,907 ; \mathrm{AVE}= \\
0.555 ; \text { Cronbachs Alfa }=0.883\end{array}$} \\
\hline $\mathrm{KD} 1$ & 4.731 & 0.913 & 0.762 \\
\hline $\mathrm{KD} 2$ & 4.308 & 1.561 & 0.700 \\
\hline KD3 & 4.346 & 1.603 & 0.741 \\
\hline $\mathrm{KD} 4$ & 4.173 & 1.370 & 0.688 \\
\hline KD5 & 4.673 & 1.368 & 0.857 \\
\hline
\end{tabular}

Komitmen terhadap Tujuan (KT); Composite reliability $=0.892$; $\mathrm{AVE}=0.734 ;$ Cronbachs Alfa $=0.820$

$\begin{array}{llll}\text { KT1 } & 5.442 & 1.335 & 0.807 \\ \text { KT2 } & 6.019 & 1.244 & 0.887 \\ \text { KT3 } & 5.269 & 1.315 & 0.875\end{array}$

Kinerja Manajerial; Composite reliability $=0.925 ;$ AVE $=0.610$; Cronbachs Alfa $=0.907$

$\begin{array}{llll}\mathrm{KM} 1 & 4.981 & 1.515 & 0.819 \\ \mathrm{KM} 2 & 5.038 & 1.357 & 0.684 \\ \mathrm{KM} 3 & 5.173 & 1.324 & 0.732 \\ \mathrm{KM} 4 & 4.865 & 1.442 & 0.849 \\ \mathrm{KM} 5 & 4.769 & 1.767 & 0.850 \\ \mathrm{KM} 6 & 4.385 & 1.728 & 0.859 \\ \mathrm{KM} 7 & 4.615 & 1.795 & 0.616 \\ \mathrm{KM} 8 & 4.308 & 1.689 & 0.807\end{array}$

Kinerja Anggaran (KA); Composite reliability $=1.000 ; \mathrm{AVE}=$ 1.000; Cronbachs Alfa = 1.000

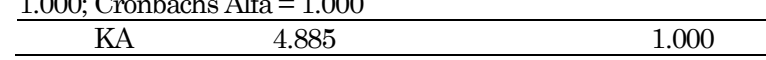

\section{Tabel 3. Korelasi Bivariat}

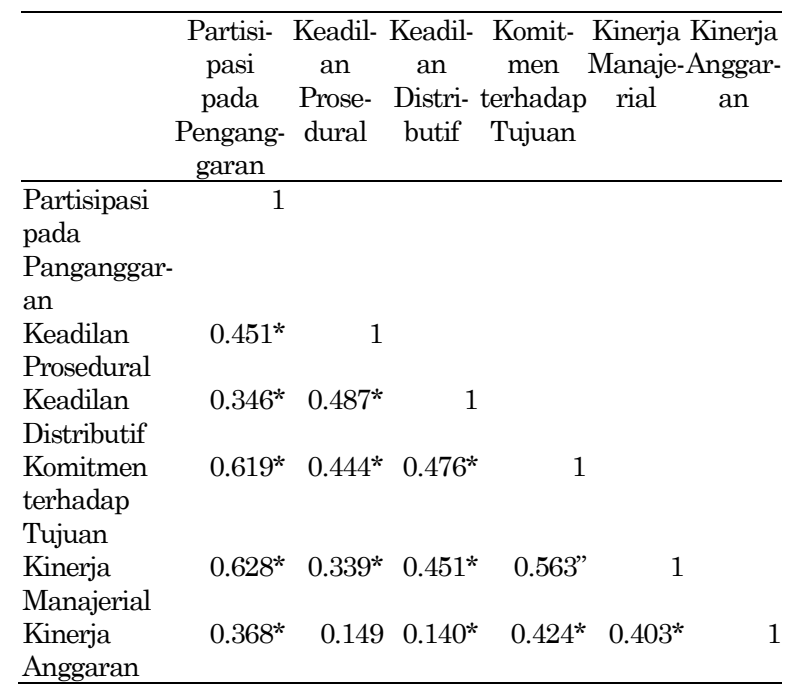

\footnotetext{
*signifikan dengan $\mathrm{p}<0,01$ (two-tail), $\mathrm{df}=60$, t-table $=2,617$
}

\section{Analisis Model Struktural}

Setelah melihat masing-masing hubungan antar variabel, peneliti melakukan analisis terhadap hubungan antar variabel di dalam model. Untuk meneliti pengaruh partisipasi pada penganggaran terhadap dua jenis kinerja (managerial dan anggaran), dibangun dua model seperti yang digambarkan pada Gambar 2 dan Gambar 3.

Berdasar Gambar 2 dan gambar 3 peneliti melakukan analisis terhadap masing-masing model secara terpisah. Hasil pengolahan data dengan menggunakan PLS pada model tersebut dilihat di Tabel 4 dan Tabel 5.

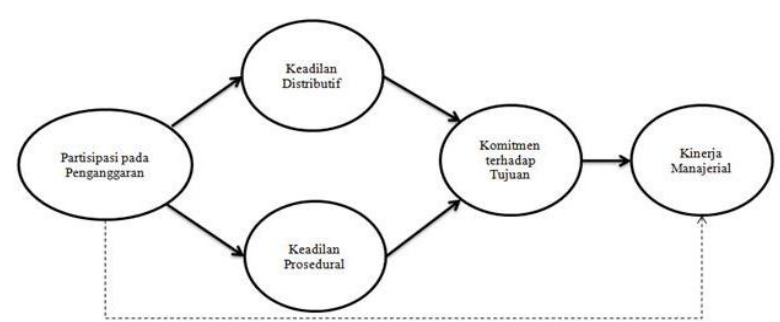

Gambar 2. Penganggaran terhadap Kinerja Manajerial

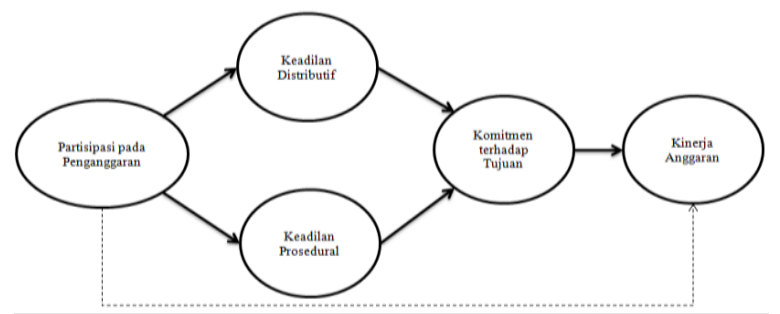

Gambar 2. Penganggaran terhadap Kinerja Anggaran

Tabel 4. Hasil PLS untuk Model 1

\begin{tabular}{lrrrr}
\hline \multicolumn{1}{c}{ Dari/Ke } & \multicolumn{3}{c}{ Keadilan } \\
& Prosedural & Keadilan & Komitmen \\
& & & $\begin{array}{c}\text { Kinerja } \\
\text { Mantibutif } \\
\text { terhadap } \\
\text { Tujuan }\end{array}$ \\
\hline Partisipasi pada & 0.395 & 0.310 & 0.485 & 0.629 \\
Penganggaran & $(5.604)^{*}$ & $(3.794)^{*}$ & $(5.082)^{*}$ & $(11.624)^{*}$ \\
Keadilan & & & 0.230 & 0.211 \\
Prosedural & & & $(2.405)^{*}$ & $(1.879)$ \\
Keadilan & & & 0.137 & 0.034 \\
Distributif & & & $(1.385)$ & $(0.240)$ \\
Komitmen & & & & 0.446 \\
terhadap Tujuan & & & & $(4.640)^{*}$ \\
Rsquare & 0.096 & 0.156 & 0.456 & 0.348 \\
\hline
\end{tabular}

*signifikan dengan $\mathrm{p}<0,01$ (two-tail), $\mathrm{df}=60, t$-table $=2,617$

Tabel 5. Hasil PLS untuk Model 2

\begin{tabular}{lrrrr}
\hline \multicolumn{1}{c}{ Dari/Ke } & \multicolumn{2}{c}{$\begin{array}{c}\text { Keadilan } \\
\text { Prosedural Distributif }\end{array}$} & $\begin{array}{c}\text { Keadilan } \\
\text { temitmen } \\
\text { tujuan } \\
\text { Tujuan }\end{array}$ & $\begin{array}{c}\text { Kinerja } \\
\text { Managerial }\end{array}$ \\
\hline Partisipasi pada & 0.307 & 0.382 & 0.491 & $0.32(9.313)$ \\
Penganggaran & $(3.747)^{*}$ & $(4.672)^{*}$ & $(5.173)^{*}$ & \\
Keadilan & & & 0.239 & -0.051 \\
Prosedural & & & $(2.390)^{*}$ & $(0.427)$ \\
Keadilan & & & 0.143 & -0.126 \\
Distributif & & & $(1.445)$ & $(1.079)$ \\
Komitmen & & & & 0.477 \\
terhadap Tujuan & & & & $(3.690)^{*}$ \\
Rsquare & 0.094 & 0.146 & 0.475 & 0.193 \\
\hline
\end{tabular}

*signifikan dengan $\mathrm{p}<0,01$ (two-tail), df=60, t-table $=2,617$ 
Dari hasil pengolahan dengan PLS, dapat diketahui bahwa partisipasi pada penganggaran berpengaruh positif (path coefficient: 0,629, $\mathrm{p}<0,01)$. Hasil tersebut mendukung H1a yang berbunyi bahwa partisipasi pada penganggaran berpengaruh secara positif terhadap kinerja manajerial. Tetapi partisipasi pada penganggaran tidak berpengaruh secara signifikan pada kinerja anggaran, sehingga tidak mendukung $\mathrm{H} 1 \mathrm{~b}$.

Hasil analisis menunjukkan kedua jenis keadilan persepsian juga berkorelasi dengan partisipasi pada penganggaran, yaitu keadilan prosedural (path coefficient: 0,395, $\mathrm{p}<0,01$ ) dan keadilan distributif (path coefficient: $0,310, p<0,01$ ), sehingga mendukung H2a dan H2b. Selain itu, partisipasi pada penganggaran berpengaruh positif pada komitmen terhadap tujuan (path coefficient: 0,485 , $\mathrm{p}<0,01$ ). Hasil tersebut mendukung H3 bahwa partisipasi pada penganggaran berpengaruh secara positif terhadap komitmen terhadap tujuan.

Pada model 1 (gambar 4) keadilan distributif tidak berpengaruh pada komitmen pada komitmen terhadap tujuan sehingga tidak mendukung H4a. Sebaliknya keadilan prosedural berpengaruh secara positif terhadap komitmen terhadap tujuan (path coefficient: $0,230, \mathrm{p}<0,01)$ sehingga mendukung H4b yang menyatakan bahwa keadilan prosedural berpengaruh secara positif terhadap komitmen terhadap tujuan. Hasil yang sama diperoleh pada model 2 (gambar 5). Komitmen terhadap tujuan berkorelasi positif pada dua jenis kinerja, kinerja managerial (path coefficient: 0,446, $\mathrm{p}<0,01$ ) dan kinerja anggaran (path coefficient: 0,477, $\mathrm{p}<0,01)$, sehingga mendukung H5a dan H5b.

Secara keseluruhan dapat dikatakan bahwa keadilan persepsian (melalui keadilan prosedural) dan komitmen terhadap tujuan memediasi hubungan antara partisipasi pada penganggaran dan kinerja (manajerial dan anggaran). Merujuk pada argumen Baron dan Kenny (1986) tentang hubungan mediasi, peran keadilan prosedural dan komitmen terhadap tujuan pada model ini adalah secara parsial, karena setelah kedua variabel tersebut dimasukkan pada model hubungan langsung antara partisipasi pada penganggaran dan kinerja tetap signifikan.

\section{KESIMPULAN DAN SARAN}

Penelitian ini bertujuan untuk mengetahui apakah partisipasi pada penganggaran mempengaruhi kinerja melalui keadilan persepsian dan komitmen untuk mencapai tujuan anggaran; dengan mereplikasi penelitian yang dilakukan Wentzel (2002), tetapi pada objek penelitian yang sangat berbeda. Jika Wentzel (2002) melakukan penelitian hubungan partisipasi pada penganggaran terhadap kinerja yang dimediasi oleh keadilan persepsian dan komitmen terhadap tujuan anggaran di sebuah rumah sakit perkotaan di Amerika Serikat, penelitian ini meneliti sebuah lembaga hukum pada sektor publik di Indonesia yang selama ini jarang dijadikan objek penelitian di ranah akuntansi keperilakuan-. Secara spesifik penelitian ini ingin mengetahui apakah partisipasi pada penganggaran mempengaruhi kinerja dan apakah keadilan persepsian dan komitmen terhadap tujuan memediasi hubungan partisipasi pada penganggaran dan kinerja

Peneliti memiliki tiga alasan penting mengapa studi ini penting untuk dilakukan: (1) penelitian yang pernah dilakukan Wentzel (2002) dilakukan di sebuah rumah sakit perkotaan di Amerika Serikat yang sedang mengalami pemotongan anggaran, sementara penelitian ini dilakukan di organisasi yang tidak mengalami pemotongan anggaran; (2) objek pada penelitian yang digunakan merupakan sektor publik di Indonesia, yang menurut Jermias dan Setiawan (2007) memiliki karakter khusus dan penting untuk dipelajari; (3) dengan meneliti objek ini peneliti ingin menganalisis pengaruh partisipasi penganggaran pada institusi nonkeuangan, setelah Jermias dan Setiawan (2007) melakukan penelitian yang serupa di organisasi sektor publik di Indonesia di bidang keuangan.

Beberapa kesimpulan pada penelitian ini mendukung generalisasi pada temuan Wentzel (2002), yaitu partisipasi pada penganggaran berhubungan dengan sangat signifikan pada keadilan distributif, keadilan prosedural, dan komitmen terhadap tujuan. Artinya, pada objek penelitian keikutsertaan karyawan dalam proses penentuan keputusan organisasi sangat mempengaruhi mereka secara emosional untuk mencapai tujuan yang telah ditetapkan. Hubungan positif antara partisipasi pada penganggaran dengan keadilan prosedural pada penelitian ini mendukung teori selfinterest model yang ditemukan oleh Lind dan Tyler (1988) dalam Wentzel (2002). Penelitian ini membuktikan bahwa hubungan antara komitmen terhadap tujuan anggaran dan kinerja adalah positif. Hal tersebut mendukung temuan Lau dan Moser (2008) dan Wentzel (2002).

Perbedaan objek pada penelitian ini dengan Wentzel (2002) menyebabkan adanya perbedaan kesimpulan pada beberapa jenis hubungan antarvariabel. Penelitian ini tidak mendukung adanya hubungan yang signifikan antara keadilan distributif dan komitmen terhadap tujuan. Selain itu, penelitian ini menemukan bahwa partisipasi pada penganggaran berpengaruh positif terhadap kinerja manajerial dan kinerja anggaran; hal tersebut 
tidak mendukung generalisasi Wentzel (2002) yang menyatakan bahwa tidak terdapat hubungan antara partisipasi pada penganggaran terhadap kinerja manajerial. Kesimpulan ini telah mendukung temuan penelitian terdahulu (Argyris 1952; Kenis 1979; Linquist 1995; Jermias dan Setiawan 2007).

Kesimpulan lain yang didapatkan dari penelitian ini adalah bentuk keadilan persepsian yang memediasi partisipasi pada penganggaran dan komitmen untuk mencapai tujuan adalah keadilan prosedural. Keadilan prosedural didefinisikan sebagai kepercayaan individu bahwa prosedur yang dialokasikan secara tepat yang memenuhi kriteria tertentu adalah adil dan tepat (Leventhal 1980 dalam Sholihin et al. 2011). Sebaliknya, keadilan distributif tidak memiliki hubungan yang signifikan terhadap partisipasi pada penganggaran dan komitmen terhadap tujuan. Leventhal (1976) mendefinisikan aturan distributif (keadilan distributif) sebagai kepercayaan individu bahwa suatu hal telah adil saat upah, hukuman, atau sumber daya yang didistribusikan telah sesuai dengan kriteria tertentu. Berdasarkan pengertian tersebut peneliti menyimpulkan bahwa meskipun nilai rata-rata persepsi keadilan distributif pada sampel cenderung tinggi, hal tersebut tidak berpengaruh pada komitmen terhadap tujuan anggaran karena keadilan pada distribusi sumber daya organisasi maupun insentif yang ada berdasar pada ketetapan yang sudah rigid.

Dalam penelitian ini terdapat berbagai keterbatasan yang harus diperhatikan: (1) jumlah sampel yang diambil relatif kecil dibandingkan dengan populasi yang ingin diteliti pada penelitian ini; (2) penggunaan kuesioner sebagai instrumen pengukur bisa jadi menghasilkan hasil yang bias, karena beberapa responden mungkin saja tidak terlalu ingin mengikuti survey yang diadakan; (3) penilaian terhadap kinerja, baik manajerial dan anggaran, yang dilakukan oleh responden berpotensi menghasilkan nilai yang tidak sesuai dengan keadaan yang sebenarnya.

Peneliti menemukan beberapa hal yang dapat dilakukan dan dieksplorasi oleh peneliti di masa depan yang melakukan studi serupa, yaitu (1) menggunakan pengukuran lain dalam mengukur kinerja, misalnya dengan melihat ketercapaian anggaran dan outcome dari data sekunder yang dikumpulkan organisasi; (2) memasukkan variabel lain untuk menilai keadilan persepsian, seperti prosedur evaluasi dan sistem reward and punishment dapat memberikan gambaran yang lebih komprehensif akan topik ini; (3) memperluas objek penelitian atau sampel, tidak hanya pada institusi publik di ranah hukum, tetapi juga lainnya; seperti kantor dinas di daerah.

Dengan berbagai keterbatasan yang ada, penelitian ini tetap memberikan kontribusi yang penting dalam menjelaskan hubungan antara partisipasi pada penganggaran terhadap kinerja di sektor publik di Indonesia.

\section{DAFTAR PUSTAKA}

Alutto, J. A., dan Belasco, J. A. (1972). A typology for participation in organizational decision making. Admistrative Science Quarterly, 17, 117-125.

Baiman, S., dan Evans, J. H. (1983). Pre-decision information and participative management control systems. Journal of Accounting Research, 21(Autumn), 371-395.

Baron, R. M. dan Kenny, D. A. (1986). The moderator-mediator variable distinction in social psychological research: conceptual, strategic, and statistical considerations. Journal of Personality and Social Psychology, 51, 1173-1182.

Becker, S. dan Green, D. (1960). Budgeting and employee behavior. Journal of Business, (October),392-402.

Brownell, P. (1982). The role of accounting data in performance evaluation, budgetary participation, and organization effectiveness. Journal of Accounting Research, (Spring), 12-27.

Clinton, B. D. dan James, E. H. (2001). Linking participative budgeting to organization performance. Behavior Research in Accounting, 13.

Colquitt, J. A., Lepine, J. A., dan Wenston, M. J. (2009). Organizational behavior: Improving performance and commitment in the workplace. New York, NY: McGraw Hill.

Doll, W. J., dan Torkzadeh, G. (1989). A discrepancy model of end user and computing involvement. Management Sciences, 35(10), 1151-117.

Fornell, C. dan Larcker, D. F. (1981). Issues in the application of covariance Structure Analysis: A comment. Journal of Consumer Research, 9, 443-448.

George, J. M., dan Jones, G.R. (2006). Contemporary management: Creating value in organizations, $4^{\text {th }}$ edition, 353. New York: McGraw Hill.

Ghozali, I. (2011). Structural Equation Modeling: Metode alternatif dengan Partial Least Square edisi 3. Badan Penerbit Universitas Diponegoro: Semarang.

Jermias, J.. dan Setiawan, T. (2007). The moderating effects of hierarchy and control systems on the relationship between budgetary participation and performance. Management Accounting Research

Hartono, J. (2008). Pedoman survei kuesioner: Mengembangkan kuesioner, mengatasi bias, dan meningkatkan respon. Badan Penerbit Fakultas Ekonomika dan Bisnis UGM. 
Kenis, I. (1979). Effect of budgetary goal characteristics on managerial attitudes and performance. The Accounting Review, 54, 707-721.

Kim, W. C., dan Maugborne, R. A. (1993). Procedural justice, attitudes, and subsidiaries top management compliance with multinationals' corporate strategic decisions. Academy of Management Journal, 36, 502-526.

Korsgaard, M.A., Schweiger, D.M., dan Sapienza, H.J. (1995). Building commitment, attachment, and trust in strategic decision making teams: The role of procedural justice. Academy of Management Journal, 38(1), 60-84.

Latham, G. P., dan Steele, T. P. (1983). The motivational effects of participation versus goal setting in performance. Academy of Management, 26, 407-417.

Lau, C. M., dan Moser, A. (2008). Behavioral effects on nonfinancial measures: The role of procedural fairness. Behavioral Research in Accounting, 20(2), 55-71.

Leventhal, G. P. (1976). What should be done with equity theory? New approaches to the study of fairness in social relationship.

Li, A., dan Butler, A. B. (2004). The effects of participation in goal setting and goal rationales on goal commitment: An exploration of justice mediators. Journal of Business and Psycho$\log y, 19(1), 37-51$.

Libby, T. (1999). The influence of voice and explanation on performance in a participative budgeting setting. Accounting, Organization, and Society, 24,125-137.

Linquist, T. M. (1995). Fairness as antecedents to participative budgeting: examining the effects of distributive justice, procedural justice and referent cognitions on satisfaction and performance. Journal of Management Accounting Research, 7(Fall), 122-147.

Locke, E. A. (1968). Toward a theory of task motivation and incentives. Organizational Behavior and Human Performance, 3, 157-189.

Locke, E. A., Lantham, G. P., dan Erez, M. (1988). The determinants of goal commitment. Academy of Management Review, 13(1), 23-39.
Magee, R. P. (1980). Equilibria in budget participation.Journal of Accounting Research, 18 (Autumn), 551-573.

McFarlin, D. B., dan Sweeney, P. D. (1992). Distributive justice nd procedural justice as predictors of satisfaction with personal and organizational outcomes. Academy of Management Journal, 35(3), 626-637.

Nouri, H., dan Parker, R.J. (1998). The relationship between budget participation and job performance: The roles of budget adequacy and organizational commitment. Accounting, Organizational, and Society, 23(5/6), 467-483.

Penno, M. (1984). Asymmetry of pre-decision information and managerial accounting. Journal of Accounting Research, 22(Spring), 177-191.

Peraturan Sekretaris Jenderal Komisi Yudisial Republik Indonesia nomor 1 tahun 2009.

Sekaran, U. (2010). Research methods for business: A skill building approach. New Jersey, NJ: John Willey and Sons.

Sholihin, M., dan Pike, R. (2009). Fairness in performance evaluation and its behavioral consequences. Accounting and Business Research, 39(4), 397-413.

Sholihin, M., Pike, R., Mangena, M., dan Li, J. (2011). Goal-setting participation and goal commitment: Examining the mediating roles of procedural fairness and interpersonal yrust in UK financial services organization. The British Accounting Review.

Tim Pusat Data dan Layanan Informasi. (2010). Buku 6 tahun Komisi Yudisial RI: Mewujudkan Profesionalitas Hakim. Komisi Yudisia Republik Indonesia: Jakarta.

Trushman, M. L., dan Naddler, D. A. (1978). Information processing as an integrating concept in organizational design. Academy of Management Review, 3(July), 613-624.

Wentzel, K. (2002). The influence of fairness perceptions and goal commitment to managers' performance in budget setting. Behavioral Research in Accounting, 14. 